Jurnal Homepage: http:/journal2.um.ac.id/index.php/jaa

\title{
Pengaruh kebijakan dividen, kebijakan hutang, profitabilitas, dan likuiditas terhadap harga saham
}

\author{
Hana Chabibatul Latifah ${ }^{1}$, Ani Wilujeng Suryani*1 \\ ${ }^{1}$ Universitas Negeri Malang, JL. Semarang No. 5 Malang, Indonesia
}

\begin{abstract}
Diterima: Agustus 2019 Direvisi: Oktober 2019 Disetujui: Desember 2019

\section{Koresponding:} Ani Wilujeng Suryani ani.suryani@um.ac.id
\end{abstract}

\section{DOI:}

http://dx.doi.org/10.17977/ um004v7i12020p31

\begin{abstract}
The purpose of this study is to understand the impact of dividend policy, debt policy, profitability, and liquidity on the stock price. By using data from 27 annual reports mining companies in Indonesia from 2008 to 2017 , we found that the profitability and liquidity affect the stock price. However, dividend policy and debt policy have no effect on the stock price. The result of this study indicated that the dividend policy and debt policy could not be used as the consideration that could affect the stock price. However, the companies and investors could use the profitability and liquidity as the consideration that could affect the stock price. The result of this study can be used by companies to improve the stock price by maintaining a good performance and balancing the proportion current debt with current assets.

Keywords: Honesty; Managerial Behavior; Managerial Reporting; Individual Preferences; Systematic Literature Review

Abstrak

Penelitian ini dilakukan untuk mengetahui sejauh mana kebijakan dividen, kebijakan hutang, profitabilitas dan likuiditas berpengaruh terhadap harga saham. Dengan menggunakan data dari 27 laporan tahunan perusahaan pertambangan di Indonesia dari tahun 2008 sampai 2017, penelitian ini menemukan bahwa profitabilitas dan likuiditas memiliki pengaruh terhadap harga saham. Namun, kebijakan dividen dan kebijakan hutang tidak berpengaruh pada harga saham. Hasil penelitian ini mengindikasikan bahwa kebijakan dividen dan kebijakan hutang belum bisa digunakan sebagai faktor pertimbangan yang dapat mempengaruhi harga saham. Namun, profitabilitas dan likuiditas dapat digunakan sebagai faktor pertimbangan yang dapat mempengaruhi harga saham. Hasil penelitian ini dapat digunakan oleh perusahaan untuk meningkatkan harga saham dengan cara menjaga kinerja perusahaan serta menyeimbangkan proporsi hutang lancar dengan aset lancar.

Kata Kunci: Harga Saham; Kebijakan Dividen; Kebijakan Hutang; Profitabilitas; Likuiditas
\end{abstract}

\section{PENDAHULUAN}

Pada saat ini masyarakat mulai sadar dengan pentingnya sebuah investasi. Investasi yang memberikan keuntungan yang cukup menjanjikan adalah investasi saham. Dividen dan capital gain merupakan keuntungan yang didapat dari berinvestasi saham (Halim, 2018:8). Sebelum melakukan keputusan investasi saham, investor perlu melakukan pengamatan ataupun pengkajian lebih lanjut terhadap saham-saham yang berpotensi menghasilkan keuntungan yang maksimal.

Investor dapat memilih sektor industri yang diperkirakan potensial untuk tujuan investasi (Sahamgain, 2018) dengan mempertimbangan risiko investasi. Investor yang berani mengambil risiko akan lebih memilih investasi melalui sektor pertambangan. Hal ini dikarenakan harga saham pada sektor pertambangan mengalami fluktuasi dengan waktu yang begitu cepat dibandingkan dengan sektor industri yang lainnnya (lihat Tabel 1). Fluktuasi ini menandakan tingginya tingkat risiko yang dihadapi, yang diharapkan memberikan tingkat pengembalian (return) yang tinggi pula (Hartono, 2014:257).

Harga saham sektor pertambangan sangat volatile, sebagai contoh pada saat kejadian krisis global. Krisis finansial global menyebabkan turunnya harga berbagai komoditas sehingga keuntungan perusahaan pertambangan menurun. Laba perusahaan pertambangan pada tahun 2008 menurun 33\% dibandingkan tahun 2007. Di Bursa Efek Indonesia (BEI), kapitalisasi pasar perusahaan pertambangan yang naik 300\% dari tahun 2006 ke 2007, turun hingga 74\% pada akhir November 2008 (Kontan, 
Tabel 1. Perkembangan Indeks Harga Saham Sektoral Tahun 2008-2017

\begin{tabular}{lcccccccccc}
\hline \multicolumn{1}{c}{ Tahun } & $\mathbf{2 0 0 8}$ & $\mathbf{2 0 0 9}$ & $\mathbf{2 0 1 0}$ & $\mathbf{2 0 1 1}$ & $\mathbf{2 0 1 2}$ & $\mathbf{2 0 1 3}$ & $\mathbf{2 0 1 4}$ & $\mathbf{2 0 1 5}$ & $\mathbf{2 0 1 6}$ & $\mathbf{2 0 1 7}$ \\
\hline Sektor Pertambangan & 878 & 2203 & 3274 & 2532 & 1940 & 1381 & 1368 & 811 & 1384 & 1594 \\
Sektor Agroindustri & 919 & 1753 & 2284 & 2146 & 2161 & 2077 & 2367 & 1719 & 1864 & 1616 \\
Sektor Perdagangan & 148 & 275 & 474 & 582 & 727 & 778 & 881 & 850 & 861 & 922 \\
Sektor Industri Dasar & 135 & 274 & 387 & 408 & 484 & 484 & 542 & 408 & 538 & 689 \\
Sektor Property & 103 & 147 & 203 & 229 & 309 & 339 & 533 & 491 & 518 & 496 \\
Sektor Manufaktur & 237 & 529 & 823 & 992 & 1150 & 1157 & 1341 & 1152 & 1369 & 1640 \\
Sektor Lainnya & 215 & 601 & 967 & 1311 & 1370 & 1177 & 1301 & 1057 & 1371 & 1381 \\
Sektor Infrastruktur & 490 & 729 & 819 & 699 & 914 & 925 & 1157 & 981 & 1056 & 1184 \\
Sektor Keuangan & 176 & 301 & 467 & 492 & 546 & 536 & 733 & 687 & 812 & 1141 \\
Sektor Konsumsi & 327 & 671 & 1095 & 1316 & 1630 & 1804 & 2205 & 2065 & 2324 & 2861 \\
\hline
\end{tabular}

Sumber: Yahoo Finance (https://finance.yahoo.com/) diakses tanggal 18 Mei 2019

27 Februari 2009). Contoh lainnya, volatilitas saham perusahaanm pertambangan ditunjukkan dengan indeks saham sektoral yang naik 53,35\% pada awal tahun 2016 hingga 14 Oktober 2016 yang dikarenakan oleh mulai membaiknya harga minyak dunia (Rahmayanti, 17 Oktober 2016).

Di tahun 2017, indeks harga saham gabungan (IHSG) juga menunjukkan volatilitas yang turun sebesar 0,75\% pada tanggal 2 Agustus 2017. Penurunan ini dipengaruhi oleh berkurangnya ekspor batu bara ke Cina dan Eropa, selain adanya pelemahan nilai tukar rupiah terhadap dolar AS. Hal ini juga menyebabkan pelemahan sektor pertambangan sebesar 2,52\%, disusul sektor saham keuangan dan infrastruktur sebesar 0,90\% (Gideon, 2017).

Salah satu analisis yang dapat dilakukan terhadap pergerakan harga saham adalah analisis fundamental yang mana harga saham akan dipengaruhi oleh kinerja keuangan perusahaan. Kinerja keuangan ini dapat dipengaruhi oleh kondisi industri atau faktor internal suatu perusahaan (Halim, 2018:30). Investor dapat melakukan analisis terhadap faktor internal yang akan berdampak pada kinerja perusahaan serta harga sahamnya (Alwi, 2003:87).

Faktor internal yang dapat dianalisis untuk menilai harga saham adalah kebijakan dividen (Syarif, dkk., 2015; Clarensia, 2012; Senata, 2016; Deitiana, 2011; Ranajee, 2018). Miller \& Modigliani (1961), Bhattacharya (1979), John \& Williams (1985), dan Miller \& Rock (1985) yang mengembangkan signaling theory of dividend menyatakan bahwa manajer sebagai orang dalam dapat menggunakan kebijakan dividen untuk menyampaikan sinyal kepada investor mengenai informasi yang tidak diketahui pihak luar. Pengumuman dividen dianggap sinyal positif oleh investor karena mengindikasikan prospek yang positif dari kinerja perusahaan (Sugeng, 2017:440). Dengan demikian, semakin tinggi dividen yang diumumkan maka harga saham juga akan semakin tinggi. Hasil pengaruh positif kebijakan dividen terhadap harga saham sesuai dengan penelitian Syarif, dkk. (2015), Clarensia, dkk. (2012), dan Senata (2016). Namun penelitian lain menunjukkan bahwa kebijakan dividen tidak berpengaruh terhadap harga saham (Deitiana, 2011). Perbedaan hasil penelitian kemungkinan dikarenakan sampel penelitian yang digunakan berbeda-beda. Berdasarkan uraian tersebut maka hipotesis mengenai kebijakan dividen terhadap harga saham adalah:

H1: Kebijakan dividen berpengaruh positif terhadap harga saham.

Selain itu, faktor internal yang dapat dianalisis untuk menilai harga saham adalah kebijakan hutang (Pasaribu, 2008; Bailia, dkk., 2016; Kesuma, 2009; Hendri, 2015). Bhattacharya (1979), John \& Williams (1985), dan Miller \& Rock (1985) yang mengembangkan signaling theory menjelaskan bahwa manajemen menggunakan kebijakan pendanaan (struktur modal) sebagai sarana menyampaikan pesan (sinyal) tentang prospek perusahaan yang diyakini oleh manajer. Kebijakan pendanaan dapat disampaikan dari laporan keuangan melalui rasio hutang terhadap modal (Sudana, 2015:24). Semakin besar proporsi hutang dalam pendanaan perusahaan, berarti perusahaan yakin dengan prosek perusahaan kedepannya karena ada keyakinan dapat memenuhi beban bunga dan pokok pinjaman hutang (Sugeng, 2017:329). Dengan demikian, kebijakan pendanaan melalui sumber hutang memberikan isyarat (sinyal) positif bagi investor tentang prospek perusahaan, sehingga mendorong naiknya harga saham. Hasil pengaruh positif kebijakan hutang terhadap harga saham sesuai dengan penelitian Pasaribu (2008) dan Bailia, dkk. (2016). Namun penelitian lain menunjukkan bahwa kebijakan dividen tidak berpengaruh terhadap harga saham (Hendri, 2015; Kesuma, 2009). Perbedaan hasil penelitian kemungkinan dikarenakan sampel penelitian yang digunakan berbeda-beda. Berdasarkan uraian tersebut maka hipotesis mengenai kebijakan hutang terhadap harga saham adalah: 
H2: Kebijakan hutang berpengaruh positif terhadap harga saham.

Selain itu, faktor internal yang dapat dianalisis untuk menilai harga saham perusahaan adalah profitabilitas (Susilawati, 2012; Deitiana, 2011; Pasaribu; 2008; Clarensia, dkk., 2012; Kesuma, 2009; Meythi, dkk, 2011). Perusahaan dapat memberikan sinyal kepada pengguna laporan keuangan dari rasio profitabilitas mengenai prospek atau kondisi perusahaan (Hermuningsih, 2012). Bhattacarya (1979) menjelaskan bahwa prospek perusahaan yang bagus dapat dilihat dari profitabilitas yang tinggi dan menyebabkan nilai perusahaan akan meningkat. Semakin tinggi nilai profitabilitas, maka penggunaan modal yang dilakukan manajemen perusahaan semakin efisien, sehingga meningkatkan kepercayaan investor terhadap perusahaan dan menyebabkan harga saham naik (Sudana, 2015:25). Hasil pengaruh positif profitabilitas terhadap harga saham sesuai dengan penelitian Susilawati (2012), Deitiana (2011), Pasaribu (2008), Clarensia, dkk. (2012), dan Kesuma (2009) Namun penelitian lain menunjukkan bahwa profitabilitas tidak berpengaruh terhadap harga saham (Meythi, dkk, 2011). Perbedaan hasil penelitian kemungkinan dikarenakan sampel penelitian yang digunakan berbeda-beda. Berdasarkan uraian tersebut maka hipotesis mengenai profitabilitas terhadap harga saham adalah:

H3: Profitabilitas berpengaruh positif terhadap harga saham.

Selain itu, faktor internal yang dapat dianalisis untuk menilai harga saham perusahaan adalah likuiditas (Clarensia, dkk. 2012; Pasaribu, 2008; Susilawati, 2012; Deitiana, 2011; Meythi, dkk, 2011; Hartuti, 2013). Signaling Theory juga dapat disampaikan melalui rasio likuiditas yaitu kemampuan perusahaan untuk membayar hutang jangka pendek pada saat jatuh tempo (Sunyoto, 2013; Spence, 1973). Perusahaan dapat memberikan pesan mengenai kondisi perusahaan kepada pengguna laporan keuangan dari rasio likuiditas. Semakin cepat hutang jangka pendek dapat dipenuhi oleh perusahaan, maka kondisi keuangan perusahaan juga akan semakin baik (Sudana, 2015:24). Hal ini akan berdampak pada kenaikan dari harga sahamnya dikarenakan investor akan percaya dengan kinerja perusahaan yang baik karena kemampuan dalam memenuhi kewajiban jangka pendeknya (Clarensia, dkk., 2012; Pasaribu, 2008). Namun penelitian lain menunjukkan bahwa likuiditas tidak berpengaruh terhadap harga saham (Susilawati, 2012; Deitiana, 2011; Meythi, dkk, 2011; Hartuti, 2013). Perbedaan hasil penelitian kemungkinan dikarenakan sampel penelitian yang digunakan berbeda-beda. Berdasarkan uraian tersebut maka hipotesis mengenai likuiditas terhadap harga saham adalah:

H4: Likuiditas berpengaruh positif terhadap harga saham.

Penelitian ini menindaklanjuti dari penelitian-penelitian sebelumnya oleh Deitiana (2011) dan Clarensia, dkk. (2012) dengan menambah variabel independen berupa kebijakan hutang dan menambah variabel kontrol berupa ukuran perusahaan dan umur perusahaan. Kebijakan hutang ditambahkan dalam penelitian ini karena melihat dari hasil penelitian terdahulu banyak yang tidak konsisten. Dalam melakukan penelitian terhadap harga saham, banyak faktor yang dapat mempengaruhinya tidak terkecuali faktor yang tidak diteliti dalam penelitian ini. Oleh karena itu penelitian ini menggunakan variabel kontrol berupa ukuran perusahaan (kapitalisasi pasar) dan umur perusahaan sebagai variabel kontrol yang juga akan mempengaruhi harga saham (Endraswati \& Novianti, 2015; Annisa \& Nazar, 2015; Herawaty, 2009; Hariyanto \& Juniarti, 2014). Penelitian ini juga menggunakan periode yang lebih panjang daripada penelitian sebelumnya yaitu tahun 20082017 agar hasil penelitian lebih akurat (Deitiana, 2011; Kesuma, 2009).

\section{METODE}

Penelitian ini merupakan penelitian ekplanasi kuantitatif yang menganalisis dan menjelaskan hubungan variabel yaitu antara variabel independen (X) kebijakan dividen, kebijakan hutang, profitabilitas, dan likuiditas dengan variabel dependen $(\mathrm{Y})$ harga saham. Penelitian menggunakan perusahaan pertambangan yang tercatat di BEI periode 2008-2017. Perusahaan pertambangan dipilih karena harga sahamnya sangat fluktuatif dalam waktu yang begitu cepat dibandingkan dengan sektor industri yang lainnnya, sehingga sangat menarik untuk diteliti (Yahoo Finance, 2019). Penelitian dilakukan selama 10 tahun (2008-2017) untuk memperoleh hasil yang lebih akurat terkait pengaruh kebijakan dividen, kebijakan hutang, profitabilitas, dan likuiditas terhadap harga saham (Deitiana, 2011; Kesuma, 2009). Sampel diambil dengan cara menggunakan metode purposive sampling. Sampel dipilih berdarkan kriteria tertentu sesuai tujuan yang tercermin dalam Tabel 2.

\section{Variabel Dependen}

Variabel dependen dalam penelitian ini adalah harga saham, yaitu closing price pada tanggal terakhir di akhir tahun seperti yang dilakukan oleh Deitiana, (2011), Clarensia, dkk., (2012), Susilawati 
Tabel 2. Pengambilan Sampel Penelitian

\begin{tabular}{ccc}
\hline No. & \multicolumn{1}{c}{ Kriteria Sampel } & Jumlah Sampel \\
\hline 1. & Perusahaan pertambangan yang terdaftar di BEI selama (2008-2017 & 28 perusahaan \\
2. & $\begin{array}{l}\text { Perusahaaan pertambangan yang listing berturut-turut selama } \\
\text { 10 tahun (2008-2017) }\end{array}$ & 27 perusahaan* \\
& Total sampel penelitian & 27 perusahaan \\
Jumlah data penelitian : jumlah sampel dikali tahun pengamatan & 270 data \\
\end{tabular}

(2012); Pasaribu, (2008) ${ }^{1}$. Harga saham sektor pertambangan antar perusahaan memiliki nilai perbedaan yang tinggi karena perbedaan jenis golongannya, sehingga penelitian ini menggunakan transformasi data dalam bentuk logaritma agar data menjadi normal (Hariscom, 2013).

Variabel Independen

\section{Kebijakan Dividen}

Pengukuran kebijakan dividen dalam kenyataannya sulit dilakukan karena tidak semua perusahaan terus melakukan pembagian dividen tiap tahunnya meskipun perusahaan mengalami keuntungan (Sugeng, 2017:406). Oleh karena itu, penelitian ini menggunakan variabel dummy, 1 jika perusahaan membagikan dividen kas, dan 0 jika perusahaan tidak membagikan dividen kas (Ranajee, 2018; Yuniarti, 2013). Dividen kas digunakan karena yang paling umum dilakukan dan dibayarkan oleh perusahaan (Sugeng, 2017:406).

\section{Kebijakan Hutang}

Kebijakan hutang dalam penelitian ini menggunakan proksi Long Term Debt to Equity Ratio (LTDER) (Hendri, 2015). LTDER digunakan untuk menghitung proporsi hutang jangka panjang dibandingkan dengan modal sendiri (Sudana, 2015:24). Penelitian ini menggunakan ukuran LTDER untuk mengukur berapa bagian rupiah modal sendiri yang menjadi jaminan hutang jangka panjang (Makiwan, 2018). Hal ini dikarenakan hutang jangka panjang melibatkan waktu pinjaman yang cukup panjang untuk kegiatan ekspansi dan perluasan usaha, sehingga keputusan harus dilakukan secara cermat (Darsono, 2015). Selain itu, sektor pertambangan juga lebih dominan menggunakan hutang jangka panjangnya untuk membiayai aset tetap perusahaan berupa alat berat untuk mendukung kegiatan operasional perusahaan (Merdiansyah, 2016).

$$
\text { LTDER }=\frac{\text { long term debt }}{\text { total equity }}
$$

\section{Profitabilitas}

Pengukuran profitabilitas dalam penelitian ini menggunakan proksi Return on Equity (ROE) (Deitiana, 2011; Clarensia, dkk., 2012). ROE digunakan untuk mengukur return atas investasi pemegang saham biasa (Brigham \& Houston, 2012:149). ROE berkaitan dengan total profitabilitas yang dapat dialokasikan ke pemegang saham sehingga membuat investor yang akan membeli saham tertarik dengan ukuran profitabilitas (Hanafi \& Halim, 1995: 179).

ROE dapat menunjukkan kemampuan perusahaan untuk memperoleh keuntungan bersih setelah pajak dengan mengunakan modal sendiri tanpa adanya hutang (Sudana, 2015:25). ROE lebih mencerminkan kemampuan perusahaan dalam memperoleh keuntungan dengan anggapan tanpa hutang sekalipun karena hutang memiliki risiko tersendiri (Kurniawan, 2017). Oleh karena itu, ROE lebih efektif untuk mengukur tingkat profitabilitas suatu perusahaan.

$$
R O E=\frac{\text { earning after taxes }}{\text { total equity }}
$$

\section{Likuiditas}

Likuiditas dalam penelitian ini menggunakan proksi Quick Ratio (QR) (Hartuti, 2013). QR

\footnotetext{
${ }^{1}$ Closing price akhir tahun dipilih karena aturan untuk menyampaikan laporan keuangan maksimum 120 hari setelah akhir tahun baru muncul di tahun 2016 (No. 29/POJK.04/2016 article 7, para 1). Selain itu, variabel keuangan lain menggunakan data laporan keuangan 31 Desember dimana jika pasar adalah pasar yang efisien maka informasi tersebut sudah tercermin dalam harga pasar.
} 
dihitung dari current assets dikurangi inventory, dan membagi hasilnya dengan current liability (Brigham \& Houston, 2012:135). QR digunakan dalam penelitian ini karena memberikan ukuran yang lebih akurat yang mana inventory dikeluarkan dari current assets karena dianggap kurang likuid dibandingkan dengan kas, surat berharga, dan piutang (Sudana, 2015: 24).

Inventory membutuhkan waktu yang lebih lama dicairkan sehingga sulit diguanakan untuk membayar hutang yang akan jatuh tempo (Kasmir, 2012:136). Perusahaan pertambangan pernah mengalami pelemahan yang disebabkan oleh kelebihan inventory batu bara akibat ekspor Amerika Serikat yang besar. Hal ini berdampak pada persediaan yang overload dan tidak terjual, sehingga persediaan sulit dicairkan untuk memenuhi kewajiban jangka pendeknya (Melani, 2013). Oleh karena itu, QR dianggap efektif untuk pengukuran tingkat likuiditas suatu perusahaan karena tidak mengikutsertakan inventory dalam memenuhi kewajiban lancarnya.

\section{Variabel Kontrol}

Variabel kontrol yang digunakan dalam penelitian ini ada dua, yaitu ukuran perusahaan dan umur perusahaan (Endraswati \& Novianti, 2015; Annisa \& Nazar, 2015; Herawaty, 2009; Hariyanto \& Juniarti, 2014). Ukuran perusahaan dalam penelitian ini menggunakan kapitalisasi pasar. Kapitalisasi pasar diukur dari natural logaritma nilai pasar ekuitas perusahaan pada akhir. Hal tersebut dilakukan dengan cara menghitung jumlah saham beredar pada akhir tahun dikalikan dengan harga pasar saham akhir tahun (Herawaty, 2009).

Variabel kontrol yang kedua adalah umur perusahaan. Umur perusahaan dihitung dari usia perusahaan berdiri sampai dengan tahun pengamatan. Umur perusahaan dapat menunjukkan seberapa lama perusahaan mampu bertahan dan dapat bersaing (Widiastuti, 2002).

\section{Pengumpulan Data}

Sumber data yang digunakan dalam penelitian ini adalah data sekunder yang bersumber dari laporan keuangan perusahaan pertambangan di BEI periode 2008-2017 yang diperoleh dari situs BEI (www.idx.co.id) dan juga Indonesian Capital Market Directory (ICMD). Harga saham diperoleh dari database galeri investasi Fakultas Ekonomi Universitas Negeri Malang.

\section{Teknis Analisis Data}

Analisis data yang digunakan dalam penelitian ini adalah regresi panel. Pendekatan yang dapat dilakukan dalam metode estimasi model regresi data panel terdapat tiga, antara lain:

\section{Pooled Least Square (PLS)}

Model ini mengasumsikan bahwa tidak ada perbedaan karakteristik individu atau waktu karena memiliki intercept tetap sehingga perilaku data antar perusahaan sama dalam berbagai kurun waktu. Model ini sama dengan metode Ordinary Least Square yang menggunakan kuadrat kecil biasa untuk mengestimsi model data panel (Yamin, dkk., 2011:200). Berikut model persamaan PLS:

$Y_{i t}=\beta_{0}+\beta_{1} X_{1}+\beta_{2} X_{2}+\beta_{3} X_{3}+\beta_{4} X_{4}+\varepsilon$

$Y_{\text {it }}=\beta_{0}+\beta_{1} X_{1}+\beta_{2} X_{2}+\beta_{3} X_{3}+\beta_{4} X_{4}+\beta_{5} Z_{1}+\beta_{6} Z_{2}+\varepsilon$

Dimana :

$\mathrm{Y}_{\mathrm{it}}=$ Harga Saham

$\beta_{0}=$ Koefisien Regresi

$\mathrm{X}_{1}=$ Kebijakan Dividen, dimana $1=$ jika perusahaan membagikan dividen kas, dan

$0=$ jika perusahaan tidak membagikan dividen kas.

$\mathrm{X}_{2}=$ Kebijakan Hutang

$\mathrm{X}_{3}=$ Profitabilitas

$\mathrm{X}_{4}=$ Likuiditas

$\mathrm{Z}_{1}=$ Ukuran Perusahaan

$\mathrm{Z}_{2}=$ Umur Perusahaan

$\varepsilon=$ Residual

\section{Fixed effect (FE)}

Model ini mengasumsikan bahwa adanya perbedaan pada konstanta (intercept) setiap perusahaan tetapi koefisien (slope) setiap perusahaan tidak berubah seiring waktu (Yamin, dkk., 2011:200). FE dapat dilakukan dengan variabel dummy yaitu menggunakan Least Square Dummy Variable (LSDV) 
dan pengelompokan data (Fixef Effect Within-Group Model). Berikut persamaannya:

$\mathrm{Y}_{\mathrm{it}}=\beta_{0 \mathrm{i}}+\beta_{1} \mathrm{X}_{1 \mathrm{it}}+\beta_{2} \mathrm{X}_{2 \mathrm{it}}+\beta_{3} \mathrm{X}_{3 \mathrm{it}}+\beta_{4} \mathrm{X}_{4 \mathrm{it}}+\varepsilon_{\mathrm{it}}$

$Y_{i t}=\beta_{0 \mathrm{i}}+\beta_{1} X_{1 \mathrm{it}}+\beta_{2} X_{2 \mathrm{it}}+\beta_{3} X_{3 \mathrm{it}}+\beta_{4} X_{4 \mathrm{it}}+\beta_{5} \mathrm{Z}_{1 \mathrm{it}}+\beta_{6} \mathrm{Z}_{2 \mathrm{it}}+\varepsilon_{\mathrm{it}}$

Dimana:

$\beta_{0 \mathrm{i}}=\beta_{0}+u_{\mathrm{i}}\left(\beta_{0}\right.$ menunjukkan koefisien regresi, yang merupkan rata-rata intercept sedangkan $u_{\mathrm{i}}$ adalah residual yang bersifat random)

$i=$ Perusahaan ke- $i$

$t=$ Periode ke- $t$

$\varepsilon_{\mathrm{it}}=$ Residual keseluruhan, serta kombinasi time series dan cross section

\section{Random Effect (RE)}

Model ini mengestimasi data panel dimana variabel residual mungkin memiliki hubungan antar waktu dan antar perusahaan. Pada model random effect perbedaan intercept diakomodasi oleh error terms masing-masing perusahaan. Penelitian ini menggunakan metode Generalized Least Square (GLS) karena memiliki kemampuan untuk mempertahankan sifat efisiensi estimatornya tanpa kehilangan sifat ketidakbiasan dan konsistensinya sehingga hasil pengujian hipotesisnya menjadi akurat (Nawatmi \& Nusantara, 1999). Berikut persamaannya:

$Y_{\text {it }}=\beta_{0}+\beta_{1} X_{1 i t}+\beta_{2} X_{2 i t}+\beta_{3} X_{3 i t}+\beta_{4} X_{4 i t}+\varepsilon_{i t}$

$\mathrm{Y}_{\mathrm{it}}=\beta_{0}+\beta_{1} \mathrm{X}_{1 \mathrm{it}}+\beta_{2} \mathrm{X}_{2 \mathrm{it}}+\beta_{3} \mathrm{X}_{3 \mathrm{it}}+\beta_{4} \mathrm{X}_{4 \mathrm{it}}+\beta_{5} \mathrm{Z}_{1 \mathrm{it}}+\beta_{6} \mathrm{Z}_{2 \mathrm{it}}+\varepsilon_{\mathrm{it}}$

$\varepsilon_{\mathrm{it}}=u_{\mathrm{i}}+v_{\mathrm{t}}+w_{\mathrm{it}}$

Dimana:

$u_{\mathrm{i}}=$ error perusahaan

$V_{\mathrm{i}}=$ error waktu

$W_{\mathrm{i}}=$ error gabungan

\section{HASIL}

\section{Statistik Deskriptif}

Statistik deskriptif mencakup variabel dependen, variabel independen, dan variabel kontrol. Hasil tersebut termuat pada Tabel 3. Nilai mean harga saham oleh perusahaan pertambangan adalah Rp 2.292,53. Harga saham perusahaan memperlihatkan nilai perusahaan di mata publik (Ermawati \& Marliyani, 2015). Pertambangan menjadi sektor yang menarik untuk tempat investasi karena harga saham yang sangat volatile, sehingga akan menguntungkan untuk investor yang berani mengambil risiko (Hartono, 2014:257). Melonjaknya harga minyak mentah dunia menyebabkan harga saham pertambangan menjadi tinggi (Rahmayanti, 2016). Nilai minimal sebesar 5 menggambarkan perusahaan memiliki harga saham yang paling rendah yaitu Rp 5 oleh perusahaan PSAB, sedangkan nilai maksimal menggambarkan nilai tertinggi harga saham sebesar Rp 50.750 oleh perusahaan ITMG. Nilai standard deviation juga mengindikasikan bahwa harga saham antar perusahaan pertambangan memiliki perbedaan yang tinggi. Hal ini mungkin disebabkan karena perbedaan jenis perusahaan diantaranya perusahaan batubara, minyak, gas bumi, logam, mineral dan batu-batuan sehingga risiko yang dihadapi juga berbeda.

Tabel 3. Statistik Deskriptif

\begin{tabular}{cccccc}
\hline & Min & Max & Mean & Std. Dev & Variance \\
\hline Y Log Harga Saham & 0.699 & 4.705 & 2.696 & 0.735 & 0.540 \\
X $_{2}$ Keb. Hutang & 0.001 & 0.998 & 0.590 & 0.232 & 0.054 \\
X $_{3}$ Profitabilitas & -0.993 & 0.836 & -0.016 & 0.315 & 0.099 \\
X $_{4}$ Likuiditas & 0.025 & 4.952 & 2.196 & 1.253 & 1.570 \\
$\mathrm{Z}_{1}$ Ln Ukuran Perusahaan & 22.437 & 32.032 & 28.225 & 2.117 & 4.482 \\
Z $_{2}$ Umur Perusahaan & 4.000 & 49.000 & 26.833 & 11.701 & 136,905 \\
\hline
\end{tabular}


Kebijakan hutang memiliki nilai mean 0,59 yang menunjukkan perbandingan antara hutang jangka panjang dengan modal sendiri sebesar 59\%. Semakin tinggi nilai rasio kebijakan hutang, maka risiko keuangan juga akan semakin besar (Sudana, 2015:24). Nilai ini berguna untuk mengantisipasi penggunaan hutang yang berlebihan dan menimbulkan kondisi yang akan membahayakan perusahaan. Hutang akan menimbulkan tanggungan perusahaan dalam bentuk pokok pinjaman dan beban bunga (Fraser \& Ormiston, 2008: 233). Nilai minimal kebijakan hutang sebesar 0,001 menggambarkan perusahaan memiliki nilai kebijakan hutang yang paling rendah sebesar 0,001 oleh perusahaan ADRO, sedangkan nilai maksimal menggambarkan nilai tertinggi kebijakan hutang sebesar 0,998 oleh perusahaan PSAB.

Profitabilitas memiliki nilai mean $-1,6 \%$, dimana nilai profitabilitas yang mendekati 0 berarti pengelolaan modal yang dilakukan perusahaan untuk memperoleh penghasilan tidak dilakukan secara efisien (Warni, 2016). Profitabilitas suatu perusahaan dikatakan buruk jika memiliki nilai kurang dari 40\% (Kasmir, 2008). Profitabilitas yang rendah dikarenakan sebesar 49\% perusahaan dalam penelitian mengalami kerugian akibat berkurangnya ekspor batu bara ke China dan Eropa (Gideon, 2017). Semakin tinggi nilai rasio profitabilitas, maka pengelolaan modal yang dilakukan oleh pihak manajemen perusahaan semakin efisien (Sudana, 2015:25). Nilai minimal profitabilitas sebesar -0,993 menggambarkan perusahaan memiliki nilai profitabilitas yang paling rendah sebesar -0,993 oleh perusahaan PSAB, sedangkan nilai maksimal oleh perusahaan BUMI yang menggambarkan nilai tertinggi profitabilitas adalah sebesar 0,836. Nilai standard deviation juga mengindikasikan bahwa profitabilitas antar perusahaan pertambangan memiliki perbedaan yang tinggi. Hal ini mungkin disebabkan karena perbedaan jenis perusahaan diantaranya perusahaan batubara, minyak, gas bumi, logam, mineral dan batu-batuan sehingga risiko yang dihadapi juga berbeda dan menyebabkan kemampuan menghasilkan laba dengan modal yang digunakan berbeda pula.

Nilai mean likuiditas sebesar 2,20 menunjukkan bahwa tingkat likuiditas perusahaan pertambangan yang cukup baik. Tingkat likuiditas yang bernilai diatas 1 berarti kemampuan perusahaan dalam melunasi hutang jangka pendeknya tergolong baik (Utami, 2018). Aset lancar perusahaan setelah dikurangi inventory yang dianggap kurang likuid memiliki jumlah yang lebih besar dari hutang lancarnya sehingga perusahaan tidak memiliki risiko hutang yang tinggi. Nilai minimal likuiditas sebesar 0,025 menggambarkan perusahaan memiliki nilai likuiditas yang paling rendah sebesar 0,025 oleh perusahaan ATPK, sedangkan nilai maksimal menggambarkan nilai tertinggi likuiditas sebesar 4,952 oleh perusahaan INCO. Nilai standard deviation juga mengindikasikan bahwa likuiditas antar perusahaan pertambangan memiliki perbedaan yang tinggi. Hal tersebut kemungkinan disebabkan karena perbedaan jenis perusahaannya, sehingga kemampuan menyelesaikan kewajiban jangka pendeknya juga berbeda.

Ukuran perusahaan yang diukur dengan Ln (kapitalisasi pasar) memiliki nilai mean 28,23. Nilai tersebut mengindikasikan bahwa ukuran perusahaan pertambangan yang tergolong tinggi dikarenakan IHSG sektor pertambangan yang tinggi dan menyebabkan kapitalisasi pasar yang tinggi pula (Saragih, 2018). Nilai minimal ukuran perusahaan sebesar 22,437 menggambarkan perusahaan memiliki ukuran perusahaan yang paling kecil sebesar 22,437 oleh perusahaan PSAB, sedangkan nilai maksimal menggambarkan ukuran perusahaan terbesar yaitu 32,032 oleh perusahaan ADRO.

Umur perusahaan memiliki nilai mean 26,83 menunjukkan bahwa rata-rata umur perusahaanperusahan pertambangan yang cukup muda. Perusahaan-perusahaan tersebut memiliki struktur kepemilikan saham yang tidak banyak terpecah atau terbagi dibandingkan perusahaan tua, sehingga harga saham akan meningkat. Nilai minimal umur perusahaan sebesar 4 menggambarkan perusahaan memiliki umur perusahaan yang paling muda sebesar 4 oleh perusahaan ADRO, sedangkan nilai maksimal menggambarkan umur tertua perusahaan sebesar 49 oleh perusahaan CTTH.

Kebijakan dividen yang diukur dengan variabel dummy, sehingga statistik deskriptifnya dilakukan terpisah pada Tabel 4. Kebijakan dividen diperoleh dari informasi bahwa sampel perusahaan yang membagikan dividen diberikan nilai 1 , dan perusahaan yang tidak membagikan deviden diberikan nilai 0 . Pembagian dividen yang dilakukan secara rutin diartikan bahwa perusahaan memiliki prospek ke depan yang bagus (Wati \& Ratnasari, 2015). Data menunjukkan bahwa 65\% perusahaan dalam

Tabel 4. Kebijakan Dividen $\left(\mathrm{X}_{1}\right)$

\begin{tabular}{crc}
\hline Keterangan & N & \% \\
\hline Tidak Membagikan dividen & 176 & 65.19 \\
Membagikan dividen & 94 & 34,81 \\
\hline Total & 270 & 100.0 \\
\hline
\end{tabular}


penelitian tidak melakukan pembagian dividen. Perusahaan biasanya jarang membagikan dividen di saat mengalami kerugian (Sugeng, 2017: 302). Namun, beberapa perusahaan yang tetap membagikan dividen tergantung pada keputusan yang diambil dalam Rapat Umum Pemegang Saham (RUPS).

\section{Analisis Korelasi}

Tabel 5 menunjukkan analisis korelasi Pearson antar variabel dependen, variabel independen, dan variabel kontrol. Hasil analisis korelasi menunjukkan bahwa kebijakan dividen, profitabilitas, dan likuiditas berhubungan positif signifikan dengan harga saham, sedangkan kebijakan hutang berhubungan negatif signifikan. Variabel kontrol yang berhubungan dengan harga saham adalah ukuran perusahaan dan umur perusahaan.

\section{Pemilihan Model Regresi Panel}

Pada pengolahan data panel, terdapat tiga pengujian yang dilakukan yaitu uji chow, uji hausman dan uji lagrange multiplier. Dalam pengujian ini, model ditentukan dari arah uji yang dilakukan (yang paling banyak). Pada data penelitian Model I dan II, dua uji megarah pada fixed effect, satu uji mengarah pada random effect, maka model yang digunakan untuk Model I dan II adalah fixed effect. Tabel 6 menunjukkan hasil regresi panel dengan Fixed Effect Model antara Model I dan Model II.

Berdasarkan Tabel 6, maka dapat diinterpretasikan bahwa apabila (kebijakan dividen), (kebijakan hutang), (profitabilitas), dan (likuiditas) masing-masing bernilai 0, maka harga saham sebesar 2,52. Apabila pengambilan keputusan mengenai kebijakan dividen meningkat 1\%, maka harga saham akan mengalami kenaikan sebesar 2,58\%. Apabila nilai kebijakan hutang meningkat 1\%, maka harga saham akan mengalami penurunan sebesar 15,77\%. Apabila nilai profitabilitas meningkat $1 \%$, maka harga saham juga akan mengalami kenaikan $62,82 \%$. Namun, apabila nilai yang meningkat $1 \%$ adalah likuiditas, maka harga saham akan mengalami peningkatan sebesar $12,17 \%$.

Tabel 6 juga menunjukkan nilai konstanta $(\alpha \alpha)$ persamaan regresi Model I dan II, yaitu semula bernilai positif $(2,52)$ menjadi negatif $(-5,21)$. Hal ini dikarenakan variabel kontrol ukuran perusahaan memiliki perbedaan nilai yang cukup besar dengan nilai tertinggi mencapai 82 triliun dan nilai terendah sebesar 6 miliar $^{1}$. Hal tersebut membuat nilai konstanta berubah menjadi negatif. Namun, perubahan dari nilai yang menjadi negatif tidak memengaruhi hasil persamaan regresi karena uji asumsi klasik telah terpenuhi dan nilai slope () tidak bernilai 0 (Dougherty, 2011).

\section{Pembahasan}

\section{Pengaruh Kebijakan Dividen terhadap Harga Saham}

Hasil pengujian menunjukkan bahwa kebijakan dividen tidak berpengaruh terhadap harga saham. Hasil penelitian ini tidak konsisten dengan penelitian oleh Syarif, dkk. (2015), Clarensia, dkk., (2012), dan Senata (2016), tetapi konsisten dengan penelitian lain Deitiana (2011). Hasil penelitian ini tidak sesuai dengan signaling theory, yang mana manajer dapat menggunakan kebijakan dividen untuk menyampaikan sinyal kepada investor mengenai informasi yang tidak diketahui pihak luar. Pengumuman dividen dianggap sinyal positif oleh investor karena mengindikasikan prospek yang positif dari kinerja perusahaan (Sugeng, 2017:440). Dengan demikian, semakin tinggi dividen yang diumumkan maka harga saham juga akan semakin tinggi (Syarif, dkk, 2015).

Penelitian ini menemukan bahwa kebijakan dividen tidak berpengaruh terhadap harga saham yang bisa disebabkan oleh kecilnya pembayaran dividen, sehingga tidak berdampak pada kemakmuran pemegang saham. Kenaikan nilai dividen tidak selalu menyebabkan naiknya harga saham perusahaan, tetapi tergantung pada laba yang diproduksi oleh aktiva-aktivanya, bukan pada bagaimana pembagian laba menjadi dividen dan saldo laba ditahan (Miller \& Modigliani, 1961; Rashid \& Rehman, 2008). Kemungkinan lain kebijakan dividen tidak mempengaruhi harga saham dikarenakan pembagian dividen dalam sampel penelitian yang sangat jarang dilakukan atau kecil.

Selain itu, kebijakan dividen tidak berpengaruh terhadap harga saham kemungkinan disebabkan oleh symmetric information yaitu manajer dan investor memiliki pandangan yang sama terkait kondisi yang sebenarnya dari perusahaan. Hal inilah yang menyebabkan harga saham menggambarkan nilai yang sebenarnya dari perusahaan (Sugeng, 2017:440). Dividen dalam hal ini tidak diperlukan untuk menyeimbangkan informasi antara manajer dan investor mengenai keadaan perusahaan. Kebijakan dividen tidak mengakibatkan reaksi pasar yang dapat mempengaruhi harga saham secara signifikan, tetapi dipengaruhi oleh permintaan dan penawaran saham di pasar modal serta kebijakan di luar fundamental perusahaan yaitu kondisi ekonomi, sosial dan politik, suku bunga serta kebijakan pemerintah (Pertiwi \& Wiagustini, 2016).

${ }^{1}$ Telah dilakukan pengujian model dari masing-masing variabel kontrol yang digunakan, ditemukan bahwa adanya pengaruh dari variabel kontrol ukuran perusahaan yang menyebabkan nilai konstanta berubah. 
Tabel 5. Analisis Korelasi Pearson

\begin{tabular}{ccccccccc}
\hline & Variabel & \multicolumn{1}{c}{$\mathbf{1}$} & $\mathbf{2}$ & $\mathbf{3}$ & $\mathbf{4}$ & $\mathbf{5}$ & $\mathbf{6}$ & $\mathbf{7}$ \\
\hline 1 & $\mathrm{Y}$ & 1.000 & & & & & & \\
2 & $\mathrm{X}_{1}$ & $0.173^{*}$ & 1.000 & & & & & \\
3 & $\mathrm{X}_{2}$ & $--0.366^{* *}$ & 0.076 & 1.000 & & & & \\
4 & $\mathrm{X}_{3}$ & $0.627^{* *}$ & 0.075 & $-0.468^{* *}$ & 1.000 & & & \\
5 & $\mathrm{X}_{4}$ & $0.538^{* *}$ & -0.012 & $-0.586^{* *}$ & $0.468^{* *}$ & 1.000 & & \\
6 & $\mathrm{X}_{5}^{* *}$ & $0.811^{* *}$ & 0.057 & $-0.493^{* *}$ & $0.668^{* *}$ & $0.535^{* *}$ & 1.000 & \\
7 & $\mathrm{Z}_{1}$ & $-0.170^{*}$ & $0.200^{*}$ & $0.216^{* *}$ & 0.079 & $-0.289^{* *}$ & $-0.202^{*}$ & 1.000 \\
\hline
\end{tabular}

**. Korelasi signifikan pada $0.001,{ }^{*}$. Korelasi signifikan pada 0.01

Tabel 6. Uji Regresi

\begin{tabular}{lrr}
\hline \multicolumn{2}{c}{ Model I } & Model II \\
\hline (Constant) & & \\
$\mathrm{X}_{1}$ Keb. Dividen & 2.5247 & -5.2098 \\
$\mathrm{X}_{3}$ Keb. Hutang & 0.0258 & 0.0002 \\
$\mathrm{X}_{3}$ Profitabilitas & -0.1577 & 0.1053 \\
$\mathrm{X}_{4}$ Likuiditas & $0.6282^{* * *}$ & 0.0075 \\
$\mathrm{Z}_{1}$ Ukuran Perusahaan & $0.1217^{* * *}$ & $0.0320^{*}$ \\
$\mathrm{Z}_{2}$ Umur Perusahaan & 0.8745 & $0.2786^{* * *}$ \\
$\mathrm{R}^{2}$ & & $-0.0034^{* *}$ \\
& & 0.9609 \\
\hline$* * *$ & & p-value signifikan pada $0.001,{ }^{* *} \cdot \mathrm{p}$-value signifikan pada $0.01,{ }^{*}$. p-value signifikan pada 0.05
\end{tabular}

\section{Pengaruh Kebijakan Hutang terhadap Harga Saham}

Hasil pengujian menunjukkan bahwa kebijakan hutang tidak berpengaruh terhadap harga saham. Hasil penelitian ini tidak konsisten dengan penelitian oleh Pasaribu (2008) dan Bailia, dkk., (2016), tetapi konsisten dengan penelitian oleh Hendri (2015) dan Kesuma (2009). Hasil ini mengindikasikan bahwa kebijakan hutang untuk sumber pendanaan yang dilakukan oleh pihak manajemen tidak berpengaruh terhadap harga saham (Hendri, 2015).

Kebijakan pendanaan dapat disampaikan dari laporan keuangan melalui rasio hutang terhadap modal (Sudana, 2015:24). Kebijakan pendanaan melalui sumber hutang bisa memberikan isyarat (sinyal) positif bagi investor tentang prospek perusahaan, sehingga mendorong naiknya harga saham (Sugeng, 2017: 329). Sinyal positif ini muncul dengan asumsi perusahaan berani memiliki tingkat hutang yang tinggi karena yakin dengan kemampuannya mengembalikan pinjaman beserta bunganya (Sugeng, 2017: 329). Namun, hasil penelitian ini menunjukkan bahwa perilaku manajemen terkait dengan pendanaan (struktur modal) tidak memberikan sinyal yang direspon oleh pasar. Dengan kata lain, besar kecilnya hutang dalam pendanaan perusahaan tidak diyakini oleh investor sebagai proksi dari prospek perusahaan di masa mendatang.

Tidak adanya pengaruh kebijakan hutang terhadap harga saham dalam penelitian ini bisa jadi disebabkan oleh kecilnya jumlah hutang jangka panjang perusahaan pertambangan dalam sampel penelitian. Hal ini dikarena pembiayaan hutang jangka panjang dari perbankan nasional cukup sulit dilakukan di Indonesia (Indrajaya, dkk., 2011). Perbankan memiliki risiko yang tinggi karena pemerintah tidak memberikan jaminan, sehingga tidak leluasa dalam penyaluran dana ke sektor pertambangan. Walaupun penggunaan modal dari hutang (ataupun ekuitas) memiliki keunggulan dan kelemahan masing-masing, dalam kondisi yang baik, perusahaan akan diuntungkan dengan pembiayaan melalui hutang karena manfaat dari biaya penggunaan hutang lebih besar daripada biaya bunga. Namun, dalam kondisi tidak terlalu tingginya tuntutan pemegang saham atas pengembalian investasi, perusahaan akan lebih diuntungkan dengan penggunaan modal melalui ekuitas (Sofyaningsih \& Pancawati, 2011).

\section{Pengaruh Profitabilitas terhadap Harga Saham}

Hasil pengujian menunjukkan bahwa profitabilitas berpengaruh signifikan positif terhadap harga saham. Hasil penelitian ini tidak konsisten dengan penelitian oleh Meythi, dkk. (2011), tetapi konsisten dengan penelitian oleh Susilawati (2012), Deitiana (2011), Pasaribu (2008), Clarensia, dkk. (2012), dan Kesuma (2009). Hasil ini mengindikasikan bahwa semakin besar profitabilitas maka harga 
saham juga akan meningkat (Sudana, 2015:25). Hal ini sudah dijelaskan pada analisis korelasi bahwa profitabilitas berkorelasi positif signifikan dengan harga saham dan sebaliknya.

Hasil penelitian ini juga sesuai dengan signaling theory yang dikemukakan oleh Bhattacarya (1979) yang menyatakan bahwa bahwa profitabilitas yang tinggi mengindikasikan prospek perusahaan yang bagus sehingga investor akan merespon positif dan nilai perusahaan akan meningkat. Nilai perusahaan yang meningkat akan menarik minat investor untuk menginvestasikan dana yang lebih tinggi pada saham suatu perusahaan sehingga menyebabkan harga saham menjadi naik.

Perusahaan yang memiliki profitabilitas yang tinggi menunjukkan seberapa efektif perusahaan dalam menghasilkan keuntungan bagi investor (Hery, 2016: 143-144). Perusahaan berupaya untuk mendapatkan laba semaksimal mungkin, karena laba merupakan salah satu indikator utama bagi keberhasilan perusahaan dan dapat menyebabkan naiknya nilai perusahaan melalui harga saham.

Penelitian ini menunjukkan hasil yang berbeda ketika menambahkan variabel kontrol berupa ukuran perusahaan dan umur perusahaan. Hasil penelitian menunjukkan tidak terdapat pengaruh yang signifikan antara profitabilitas terhadap harga saham. Hal ini disebabkan karena pengaruh variabel kontrol berupa ukuran perusahaan dan umur perusahaan yang lebih dominan terhadap harga saham, sehingga pengaruh profitabilitas menjadi lebih kecil dan tidak signifikan (Endraswati \& Novianti, 2015).

\section{Pengaruh Likuiditas terhadap Harga Saham}

Hasil pengujian menunjukkan bahwa likuiditas berpengaruh positif signifikan terhadap harga saham. Hasil penelitian ini tidak konsisten dengan penelitian oleh Susilawati (2012), Deitiana (2011), Meythi, dkk., (2011), dan Hartuti (2013), tetapi konsisten dengan penelitian oleh Clarensia, dkk., (2012) dan Pasaribu (2008). Hasil ini mengindikasikan bahwa kemampuan perusahaan dalam memenuhi hutang jangka pendeknya berpengaruh signifikan positif terhadap harga saham (Clarensia, dkk., 2012; Pasaribu, 2008). Semakin cepat perusahaan dapat melunasi hutang jangka pendeknya, maka nilai perusahaan dalam masyarakat juga akan meningkat yang tercermin dari harga sahamnya (Clarensia, dkk., 2012). Hal ini dikarenakan investor akan yakin dengan kinerja perusahaan yang baik karena kemampuan dalam memenuhi kewajiban jangka pendeknya. Hal ini sudah dijelaskan pada analisis korelasi bahwa likuiditas berkorelasi positif signifikan dengan harga saham dan sebaliknya.

Hasil penelitian ini juga sesuai dengan signaling theory yang dikembangkan oleh Bhattacharya (1979), John \& Williams (1985), dan Miller \& Rock (1985) yang menjelaskan bahwa manajemen menggunakan kebijakan pendanaan (struktur modal) sebagai sarana menyampaikan pesan (sinyal) tentang prospek perusahaan yang diyakini oleh manajer. Isi pesan tersebut sebenarnya merupakan insider atau private information yang hanya dikuasai oleh manajer yang ingin disampaikan kepada publik (investor dan kreditor) yang melekat pada kebijakan pendanaan.

Jika perusahaan memutuskan menggunakan hutang dalam pendanaanya, berarti perusahaan yakin dengan prospek perusahaan kedepannya karena ada keyakinan dapat memenuhi beban bunga dan pokok pinjaman (Sugeng, 2017:329). Semakin cepat perusahaan dapat melunasi hutang jangka pendeknya, maka harga saham juga akan semakin meningkat (Clarensia, 2012; Pasaribu, 2008). Investor akan percaya dengan kinerja perusahaan yang baik karena kemampuan dalam memenuhi kewajiban jangka pendeknya.

\section{SIMPULAN}

Penelitian ini berfokus pada pengaruh kebijakan dividen, kebijakan hutang, profitabilitas dan likuiditas terhadap harga saham pada perusahaan pertambangan di Indonesia tahun 2008-2017. Berdasarkan pengujian yang telah dilakukan, maka terdapat empat kesimpulan. Pertama, kebijakan dividen tidak berpengaruh terhadap harga saham. Hal ini menunjukkan bahwa seberapa rutin dividen dibayarkan, maka tidak akan berpengaruh terhadap harga saham. Kedua, kebijakan hutang tidak berpengaruh terhadap harga saham. Hasil ini menunjukkan bahwa besar kecilnya penggunaan hutang dalam struktur modal perusahaan tidak akan berpengaruh terhadap harga saham. Perusahaan yang ingin meningkatkan harga sahamnya tidak dapat menggunakan kebijakan dividen dan kebijakan hutang sebagai pertimbangan informasi masukan.

Ketiga, profitabilitas berpengaruh positif signifikan terhadap harga saham. Profitabilitas yang tinggi menggambarkan prospek perusahaan yang bagus sehingga investor akan tertarik terhadap perusahaan dan mengakibatkan kenaikan harga saham. Perusahaan yang ingin meningkatkan harga sahamnya harus menjaga kinerja perusahaan tetap baik. Hal tersebut akan berdampak pada peningkatan profitabilitas, sehingga harga saham juga meningkat. Calon investor yang akan melakukan investasi saham dapat melakukan pertimbangan pada perusahaan dengan tingkat profitabiltas yang tinggi agar mendapatkan keuntungan yang maksimal. Namun, penelitian menunjukkan hasil yang 
berbeda ketika menambahkan variabel kontrol berupa ukuran perusahaan dan umur perusahaan. Hasil penelitian menunjukkan tidak terdapat pengaruh yang signifikan antara profitabilitas terhadap harga saham dikarenakan pengaruh variabel kontrol berupa ukuran perusahaan dan umur perusahaan yang lebih dominan terhadap harga saham sehingga pengaruh profitabilitas menjadi lebih kecil dan tidak signifikan. Calon investor dapat melakukan pertimbangan pada perusahaan dengan umur yang muda sebelum melakukan investasi saham dan ukuran perusahaan yang besar agar mendapatkan keuntungan yang maksimal.

Keempat, likuiditas berpengaruh positif signifikan terhadap harga saham. Semakin cepat perusahaan dapat membayar hutang jangka pendeknya akan membuat minat investor terhadap perusahaan semakin meningkat sehingga harga saham juga akan meningkat. Perusahaan yang ingin meningkatkan harga sahamnya dapat mengontrol tingkat maksimum utang lancarnya sehingga dapat terpenuhi oleh aset lancarnya. Perusahaan dengan tingkat likuiditas yang tinggi dapat menjadi pertimbangan untuk tempat investasi saham karena harga sahamnya juga akan relatif tinggi pula.

Hasil penelitian ini dapat menjadi bahan pertimbangan dalam pengambilan keputusan oleh beberapa pihak. Bagi investor, hasil penelitian ini dapat digunakan sebagai bahan untuk pertimbangan ketika melakukan investasi saham. Investor dapat mempertimbangkan faktor-faktor yang dapat mempengaruhi harga saham. Bagi perusahaan, hasil penelitian berguna dalam pengambilan keputusan dimasa yang akan datang yang berkaitan dengan informasi yang bersifat fundamental. Bagi calon peneliti selanjutnya, dapat digunakan dalam menambah informasi terkait dengan bidang penelitian mengenain harga saham.

Walaupun telah memberikan kontribusi dalam praktik, penelitian ini memiliki keterbatasan dimana kebijakan dividen diukur dari apakah perusahaan membagikan dividen atau tidak. Saran untuk penelitian selanjutnya diharapkan dapat memperpanjang waktu periode penelitian untuk membuat data harga saham menjadi normal. Selain itu juga menggunakan ukuran rasio dalam mengukur kebijakan dividen sehingga menghasilkan data yang lebih akurat karena memiliki besaran. Tidak berpengaruhnya kebijakan dividen terhadap harga saham bisa jadi disebabkan adanya time lag. Penelitian berikutnya bisa menggunakan closing price tahun t untuk dibandingkan dengan kinerja keuangan tahun $\mathrm{t}-1$.

\section{DAFTAR RUJUKAN}

Alwi, Z. I. (2003). Pasar Modal : Teori dan Aplikasi. Edisi Pertama. Jakarta: Nasindo Internusa.

Annisa, I.N. \& Nazar , M. R. (2015). Pengaruh Struktur Kepemilikan dengan Variabel Kontrol Profitabilitas, Umur, dan Ukuran Perusahaan terhadap Luas Pengungkapan Corporate Social Responsibility. e-Proceeding of Management, 2(1): 313-323.

Bailia, F. F. W., Tommy, P., Baramulli, D.N. (2016). Pengaruh Pertumbuhan Penjualan, Dividend Payout Ratio dan Debt to Equity Ratio Terhadap Harga Saham Pada Perusahaan Property Di Bursa Efek Indonesia. Jurnal Berkala Ilmiah Efisiensi, 16(3).

Bhattacharya, S. (1979). Imperfect information, dividend policy, and "the bird in the hand" fallacy. The Bell Journal of Economics, 19(1), pp. 259-270.

Brigham, E. F. \& Houston, J. F. (2012). Dasar-Dasar Manajemen Keuangan. Edisi 11. Buku 1. Jakarta: Salemba Empat.

Clarensia, J. (2012). Pengaruh Likuiditas, Profitabilitas, Pertumbuhan Penjualan, dan Kebijakan Dividen Terhadap Harga Saham (Studi Empirik pada Perusahaan Manufaktur yang Terdaftar di Bursa Efek Indonesia Tahun 2007-2010). Jurnal Akuntansi dan Keuangan. 1(1): 72-88.

Darsono, W. S. H. (2015). Pengaruh Struktur Utang terhadap Kinerja Perusahaan (Studi Empiris Pada Perusahaan Manufaktur Tahun 2011-2013). Diponegoro Journal of Accounting, 4(3), 1-10.

Deitiana, T. (2011). Pengaruh Rasio Keuangan, Pertumbuhan Penjualan dan Dividen Terhadap Harga Saham. Jurnal Bisnis dan Akuntansi, 13(1): 57-66.

Dougherty, Christopher. (2011). Introduction to econometrics. (Online), (https://books.google. co.id/books?hl=id\&lr=\&id=UXucAQAAQBAJ\&oi=fnd\&pg=PP2\&dq=Dougherty,+ C.+2 002.+Introduction+to + econometrics.\&ots $=8 \mathrm{MSHydb} 1$ ho\&sig $=$ hzNpgX5ktf9U-5eKXnJk W12cpo\&redir_esc=y\#v=onepage\&q=Dougherty\%2C\%20C.\%202002.\%20Introduction\%20to\%20 econometrics.\&f=false), diakses 1 Februari 2019.

Endraswati, H. \& Novianti, A. (2015). Pengaruh Rasio Keuangan dan Harga Saham dengan E 
PS sebagai Variabel Moderasi pada Perusahaan Manufaktur yang Terdaftar di DES. Jurnal Muqtasid, 6(1): 59-80

Ermawati \& Marliyani, R. (2015). Analisis Faktor-Faktor Yang Mempengaruhi Tingkat Harga Saham

Pada Perusahaan Makanan dan Minuman Yang Go Publik di BEJ. UPN Veteran Jakarta, 36-50.

Fraser, L. M. \& Ormiston, A. (2008). Memahami Laporan Keuangan. Yogyakarta: Indeks.

Gideon, A. (2017). Sektor Pertambangan Melemah Tajam, IHSG Turun ke 5.780,57. (Online), (https://www.liputan6.com/bisnis/read/3045691/sektor-pertambangan-melemah-tajam-ihsg-turunke-578057), diakses 25 September 2018.

Halim, A. (2018). Analisis Investasi dan Aplikasinya: Dalam Aset Keuangan dan Aset Riil. Edisi 2. Jakarta: Salemba Empat.

Hanafi, M.M. \& Halim, A. (1995). Analisis Laporan Keuangan. Yogyakarta: UPP STIM YKPN.

Hariscom. (2013). Transformasi Data. (Online), (http://hariscompwt.blogspot.com/2013/02/ transformasi-data.html), diakses 3 Maret 2019.

Hariyanto, L. \& Juniarti. (2014). Pengaruh Family Control, Firm Risk, Firm Size dan Firm Age terhadap Profitabilitas dan Nilai Perusahaan pada Sektor Keuangan. Business Accounting Review. 2(1): $141-150$

Hartono, J. (2014). Teori Portofolio dan Analisis Investasi. Yogyakarta: BPFE-Yogyakarta.

Hartuti, S. (2013). Pengaruh Beberapa Rasio Keuangan Terhadap Harga Saham Pada Industri Perbankan Yang Terdaftar Di Bursa Efek Indonesia.

Hendri, E. (2015). Pengaruh Debt to Asset Ratio (DAR), Long Term Debt to Equity Ratio (LTDER) dan Net Profit Margin (NPM) Terhadap Harga Saham Pada Perusahan Perbankan Yang Terdaftar Di Bursa Efek Indonesia. Jurnal Media Wahana Ekonomika, 12(2): 1 - 19.

Herawaty, V. (2009). Peran Praktek Corporate Governance Sebagai Moderating Variable dari Pengaruh Earnings Management Terhadap Nilai Perusahaan. Jurnal akuntansi dan Keuangan, 10(2). 97-108.

Hermuningsih, S. (2012). Pengaruh Profitabilitas, Size terhadap Nilai Perusahaan dengan Sruktur Modal sebagai Variabel Intervening. Jurnal Siasat Bisnis, 16(2), 232-242.

Hery. (2016). Analisis Laporan Keuangan Integrated and Comprehensive Edition. Jakarta: Kompas Gramedia.

Hidayat, A. (2014). Penjelasan Metode Analisis Regresi Data Panel. (Online), (https://www.statistikian. com/2014/11/regresi-data-panel.html), diakses 14 Februari 2019.

Indrajaya, G., Herlina, Setiadi, R. (2011). Pengaruh Struktur Aktiva, Ukuran Perusahaan, Tingkat Pertumbuhan, Profitabilitas dan Risiko Bisnis Terhadap Struktur Modal: Studi Empiris Pada Perusahaan Sektor Pertambangan yang Listing di Bursa Efek Indonesia Periode 2004-2007. Akurat Jurnal Ilmiah Akuntansi, 6(2).

John, K. \& Williams, J. (1985). Dividends, Dilution, and Taxes: A Signalling Equilibrium. The Journal of Finance, 40(4): 1053-1070.

Kasmir. (2008). Analisis Laporan Keuangan. Jakarta: Rajawali Pers.

Kasmir. (2012). Analisis Laporan Keuangan. Jakarta : PT. Raja Grafindo Persada.

Kesuma, A. (2009). Analisis Faktor yang Mempengaruhi Struktur Modal Serta Pengaruhnya Terhadap Harga Saham Perusahaan Real Estate yang Go Public di Bursa Efek Indonesia. Jurnal Manajemen dan Kewirausahaan. 11(1). 38-45.

Kontan. (2009). Laba Perusahaan Tambang Publik 2008 Anjlok 33\%. (Online), (https://investasi.kontan. co.id/news/laba-perusahaan-tambang-publik-2008-anjlok-33), diakses 21 September 2018.

Kurniawan, R. (2017). Rasio Fundamental: ROA dan ROE. (Online), (http://rivankurniawan. com/2017/11/21/apa-itu-roa/), diakses 15 Maret 2019.

Makiwan, G. (2018). Analisis Rasio Leverage untuk Memprediksi Pertumbuhan Laba Perusahaan Manufaktur Sub Sektor Makanan dan Minuman yang terdaftar di Bursa Efek Indonesia Periode 2011-2015. Jurnal Bisnis, Manajemen dan Informatika, 15(2), 147-172. 
Melani, A. (2013). Sektor Tambang Masih Melemah. (Online), (https://pasarmodal.inilah.com/read/ detail/1943526/2013-sektor-tambang-masih-melemah), diakses 16 Maret 2019.

Merdiansyah, R. (2016). Pengaruh Likuiditas dan Solvabilitas Terhadap Profitabilitas (Studi pada Perusahaan Pertambangan yang Terdaftar di Bursa Efek Indonesia Periode 2010-2014). Jurnal Ekonomi dan Bisnis. 2(2): 101-113.

Meythi, En, T. K., \& Rusli, L. (2011). Pengaruh Likuiditas dan Profitabilitas Terhadap Harga Saham Perusahaan Manufaktur yang Terdaftar di Bursa Efek Indonesia. Jurnal Bisnis Manajemen dan Ekonomi, 19(2): 2671-2684

Miller, M. H. \& Modiglin, F. (1961). Dividend Policy, Growth, and The Valuation of Shares. The Journal of Business, 34(4): 411-433.

Miller, Merton H. \& Rock, Kevin. (1985). Dividend Policy under Asymmetric Information. The Journal of Finance. Vol. XL, No. 4.

Nawatmi, S \& Nusantara, A. (1999). General Least Square : Solusi atas Gejala Heteroskedastisitas. Jurnal Bisnis dan Ekonomi. Maret 1999.

Pasaribu, R.B.F. (2008). Pengaruh Variabel Fundamental terhadap Harga Saham Perusahaan Go Public di Bursa Efek Indonesia (BEI) Periode 2003-2006. Jurnal Ekonomi dan Bisnis, 2 (2): 101113.

Pertiwi, N. K. R. A \& Wiagustini, N.L.P. (2016). Reaksi Pasar terhadap Peristiwa Stock Dividend pada Perusahaan yang Terdaftar di Bursa Efek Indonesia. E-Jurnal Manajemen Unud, 5(10): 6373-6400.

Rahmayanti, E. (2016). Indeks Sektor Pertambangan Menguat 53\% Sepanjang 2016, Penopang Utama IHSG?. (Online), (https://www.bareksa.com/id/text/2016/10/17/indeks-sektorpertambanganmenguat-53-sepanjang-2016-penopang-utama-ihsg/14103/analysis), diakses 22 September 2018.

Ranajee, R., Pathak, R., \& Saxena, A. (2018). "To pay or not to pay: what matters the most for dividend payments?.” International Journal of Managerial Finance, 14(2), 230-244. doi:10.1108/ ijmf-07-2017-0144.

Rashid, A. and Rehman, A. Z. M. A. (2008). Dividend Policy and Stock Price Volatility: Evidence

from Bangladesh. Journal of Applied Business and Economics, 8(4), 71-80.

Sahamgain. (2018). Memilih Saham untuk Investasi. (Online), (http://www.sahamgain.com/2018/07/ memilih-saham-untuk-investasi.html), diakses 15 Oktober 2018.

Saragih, H. P. (2018). Sektor Pertambangan Penopang IHSG di Awal 2018. (Online), (https://www. cnbcindonesia.com/market/20180128212326-17-2740/sektor-pertambangan-penopang-ihsg-diawal-2018), diakses 3 Maret 2019.

Senata, M. (2016). Pengaruh Kebijakan Dividen terhadap Nilai Perusahaan yang tercatat pada Indeks LQ-45 Bursa Efek Indonesia. Jurnal Wira Ekonomi Mikroskil. 6(1), 73-84.

Sofyaningsih, S. \& Pancawati, H. (2011). Struktur Kepemilikan, Kebijakan Dividen, Kebijakan Hutang, dan Nilai Perusahaan. Jurnal Ekonomi dan Bisnis. 3(1): 68-87.

Spence, M. (1973). Job Market Signaling. The Quarterly Journal of Economics, 873): 355-374.

Sudana, I.M. (2015). Teori \& Praktik Manajemen Keuangan Perusahaan. Jakarta: Erlangga.

Sugeng, B. (2017). Manajemen Keuangan Fundamental. Yogyakarta: Deepublish.

Susilawati, C.D.K. (2012). Analisis Perbandingan Pengaruh Likuiditas, Solvabilitas, dan Profitabilitas Terhadap Harga Saham pada Perusahaan LQ 45. Jurnal Akuntansi. 4(2): 165-174.

Syarif, I \& Ali, A. (2015). Effect of Dividend Policy on Stock Prices. Journal of Management. 6(1), 55-85.

Utami, N.W. (2018). Menghitung Rasio Likuiditas untuk Mengetahui Kinerja Keuangan Perusahaan. (Online), (https://www.jurnal.id/id/blog/2018-cara-menghitung-rasio-likuiditas/), diakses 17 Maret 2019.

Warni, S. (2016). Mengingat kembali mengenai ROI dan ROE. (Online), (https://zahiraccounting. com/id/blog/mengingat-kembali-mengenai-roi-dan-roe/), diakses 6 April 2019. 
Wati, N. K. P. B., \& Ratnasari, M. M. (2015). Rasio Pasar dan Harga Saham di Bursa Efek Indonesia Periode 2009-2013. E-Jurnal Akuntansi. 10(1): 279.

Widiastuti, H. (2002). Pengaruh Luas Ungkapan Sukarela dalam Laporan Tahunan terhadap Earning Response Coefficient (ERC). Journal of Accounting and Investment, 5(2)

Yamin, S., Rachmah, L. A., \& Kurniawan, H. (2011). Regresi dan Korelasi dalam Genggaman Anda. Jakarta: Salemba Empat.

Yuniarti, A.M.D. (2013). Pengaruh Kepemilikan Manajerial, Dividen, Profitabilitas dan Struktur Aset terhadap Kebijakan Hutang. Accounting Analysis Journal, 2(4), 447-454. 